\title{
AMETIKEELE OSKUSE MÕõTMINE: TEKST JA ÜLESANNE EESTI KEELE KUI TEISE KEELE KUULAMISTESTIS
}

\author{
Tiina Kikerpill, Ülle Türk
}

\begin{abstract}
Ülevaade. Ehkki eesti keele kui teise keele oskuse mõõtmisega on tegeldud juba kümmekond aastat, on peamiselt koostatud üldkeeleoskust mõõtvaid teste. Ametikeele oskuse mõõtmine on paraku jäänud tähelepanu alt välja. Seetõttu pakkus EL Phare projekt "Eesti keele oskuse arendamine mitte-eesti õppekeelega kutseõppeasutustes" tänuväärse võimaluse luua kuulamistestid kutsekoolide eri erialade õppijatele. Artiklis käsitletakse nende testide koostamist. Vaadeldakse keeleoskuse eri mudeleid ning eriotstarbelise keeleoskuse eripära, kuulamisoskuse aspekte, suuliste tekstide eripära ja kirjalike tekstide suuliseks kohandamise põhimõtteid, ülesandetüüpide valikuprintsiipe ning kuulamistestide koostamise protsessi. Kuulamistestide koostamise teeb eriti raskeks sobivate tekstide vähesus, mistõttu suur osa ajast kulub tekstide kohandamisele või koostamisele. Ülesannete koostamisel tuleb silmas pidada seda, kuidas vastavat teksti tavaelus kuulatakse, ja ka seda, et kasutataks erinevaid ülesandetüüpe.
\end{abstract}

Võtmesõnad: eesti keel teise keelena, keeletestid, kuulamisoskuse arendamine ja mõõtmine

Eestis on eesti keele kui teise keele oskuse mõõtmisega tegeldud üle kümne aasta, kuid nii eesti keele tasemeeksamite kui ka põhikooli lõpueksami ja gümnaasiumi riigieksami puhul mõõdetakse üldkeeleoskust. Samas tähendab eesti keele riigikeele staatus, et mitte-eestlased peavad suutma eesti keeles ka tööalaselt suhelda. Vene õppekeelega kutsekoolides õpetatakse küll erialaspetsiifilist eesti keelt, kuid teste selle oskuse mõõtmiseks ei ole loodud. Üheks katseks seda tühikut täita on EL Phare projekti "Eesti keele oskuse arendamine mitte-eesti õppekeelega kutseõppeasutustes" käigus aastatel 2004 ja 2005 loodud kuulamisoskuse mõõtmise testid kümnele erialale. 
Käesolevas artiklis mõtestatakse projekti raames omandatud kuulamistestide koostamise kogemust. Vaadeldakse kuulamistestide koostamise protsessi alates konstrukti määratlemisest ning sobivate tekstide leidmisest või tekstide sobivaks kohandamisest ülesandetüüpide valimise ja ülesannete koostamiseni välja. Kuna eesmärgiks on käsitleda kuulamistestide koostamise problemaatikat, siis testide läbiviimisel ja tulemuste analüüsil peatume vaid põgusalt.

\section{Lähteülesanne}

Projekti "Eesti keele oskuse arendamine mitte-eesti õppekeelega kutseõppeasutustes” eesmärgiks oli anda vene õppekeelega kutseõppeasutuste õpilastele ja õpetajatele eestikeelses töö- ja õpikeskkonnas viibimise kogemus, mille kaudu sooviti muuhulgas parandada nende eesti keele oskust. Eesti õppekeelega kutseõppeasutustes käis 2004/2005. õppeaastal lähetusel 100 vene õppekeelega kutsekoolide õpilast 10 erialalt. Et välja selgitada, mil määral nende eesti keele oskus kolme nädala jooksul tegelikult paranes, oli projektis ette nähtud testida ópilaste eesti keele oskust enne lähetusele minekut ja praktika lõppedes.

Eesti keele oskuse mõõtmise testi koostamist enda peale võttes andsime endale täielikult aru, et keeleoskuse omandamine on pikaajaline, pidevat tööd nõudev protsess ja on äärmiselt ebatõenäoline, et ilma intensiivse keeleõppeta (ja seda projekt ette ei näinud) toimub kolme nädala jooksul õppijate keeleoskuse mõõdetav paranemine. Hästi läbi mõeldud ja põhjalikult ette valmistatud lühiajaline keelekeskkonnas viibimine lisab õpilastele kindlasti julgust õpitavat keelt kasutada ja aitab paremini mõista sihtkultuuri, kuid ei tõsta märgatavalt õpilaste keeleoskuse taset.

Kõige valiidsem olnuks õpilaste keeleoskuse mõõtmiseks kasutada intervjuusid, sest eeldatavasti mõjutab keelekeskkonnas viibimine kõige enam just suulise suhtlemise oskust ja valmidust osaleda vestluses. Paraku on intervjuude usaldusväärne hindamine keeruline, samuti on intervjuude läbiviimine ajamahukas. Seetõttu otsustasime mõõta õpilaste kuulamisoskust, sest eesti keeles loengute kuulamine ja vestluses osalemine peaksid ka seda oskust arendama.

Kuna eesmärgiks oli mõõta projektis osalenute keeleoskuse paranemist, oli kuulamistestide koostamiseks vaja ligilähedaselt teada testitavate keeleoskuse taset. Liiga kerge või liiga raske test ei anna aga õppija keeleoskusest adekvaatset ettekujutust: liiga kerge testi puhul oleksid õpilased juba enne lähetust sooritanud testi maksimaalsele tulemusele, liiga raske testi puhul aga oleks tulemus nii madal, et õigeid vastuseid võiks pidada juhuslikkuseks.

Paraku oli meil õpilaste eesti keele oskuse kohta liiga vähe andmeid, et täie kindlusega otsustada, millisele tasemele peaks test vastama. Kõik õpilased olid küll täitnud ankeedi, kuhu nad muuhulgas märkisid ka, milline eesti keele eksam on sooritatud ja kui heaks nad ise oma eesti keele oskust hindavad, kuid eksamid olid enamasti sooritatud rohkem kui aasta tagasi ja meil ei olnud võimalik kontrollida, kuivõrd usaldusväärne oli õpilaste enesehinnang. Hoolimata sellest, kas sooritatud oli algtaseme (A2/B1) või kesktaseme (B2) eesti keele eksam, märkis enamik küsitletutest, et saavad eesti keeles raskustega hakkama. Seetõttu otsustasime, et meie koostatavad kuulamistestid peaksid olema veidi madalamal tasemel kui 
eesti keele kesktaseme eksam - vastama Euroopa Nõukogu keeleoskustasemete süsteemi B1/B1+ tasemele.

Euroopa keeleõppe raamdokumendi järgi (vt Hausenberg jt 2004: 44-46, CEF 2001: 66-68):

1) mõistab B1 tasemel õppija nii monoloogilist kui dialoogilist lühemat kõnet tuttavatel teemadel: töö, kool, puhkus. Saab aru üldisest igapäevaelu või tööga seotud faktilisest teabest ja mõistab ka detaile, kui kõne on selge;

2) suudab B1+ tasemel ôppija jälgida oma eriala loengut või kõnelust, kui teema on tuttav ja ettekanne selge struktuuriga. Raadio ja lindistuste kuulamisel mõistab suurema osa saadete põhisisu, kui esitus on selge ja teema isikule huvi pakkuv.

Eeldatud keelekasutusolukordi (õppetöös osalemine ja kaaslastega suhtlemine) silmas pidades koostasime kahest tekstist koosnevad testid, millest esimene oli üldkeelne tööteemaline vestlus kahe inimese vahel ja teine eriala mingile aspektile keskenduv lühiloeng. Esimese teksti juurde kuulus 9 kolme valikuga valikvastustega küsimust ja teise teksti juurde 6-18 eritüübilist küsimust. Kuna lähetuses osalenud õpilased sooritasid sama testi nii lähetuse alguses kui lõpus, koostasime kokku 10 testi.

\section{Üldkeeleoskus ja eriotstarbeline keeleoskus}

Et mingit oskust mõõta, tuleb see oskus kui mõõtmise objekt ehk konstrukt esmalt määratleda. Antud juhul oli esmaseks küsimuseks, kuivõrd erialaspetsiifilised peaksid koostatavad tekstid olema ja mida erialaspetsiifilisus kuulamisteksti puhul tähendab. Tihti keskendutakse erialakeele tundides terminoloogia omandamisele. Ometigi on ametikeele oskus märksa laiem, sest teatud ameti esindaja peab suutma tööalaselt suhelda nii ametikaaslaste kui ka klientidega. Esimesel juhul võidakse üksteisest aru saada ka ühist suhtluskeelt omamata, teisel juhul muutub aga tihti määravaks üldkeele oskus. Samuti on ametikeele oskust vaja mitte üksnes suhtlemiseks vaid ka oma valdkonnas toimuvaga kursis olemiseks. Teisisõnu on pelgalt terminoloogia tundmisest vähe abi - seda tuleb osata eesmärgipäraselt kasutada.

Seega on ametikeel kui eriotstarbeline keelekasutus (ingl specific purpose language ability) üks keeleoskuse variante ning selle määratlemine sõltub suuresti sellest, mida mõeldakse keeleoskuse all üldisemalt. Arusaamine keeleoskusest on aga aja jooksul muutunud. Kui esialgu mõisteti keeleoskust kui grammatika, sõnavara ja õige häälduse tundmist, siis hiljem on lisandunud keeleoskuse mudelisse ka osaoskused (kuulamine, lugemine, rääkimine, kirjutamine) (Lado 1961, Carroll 1961, mõlemad Hausenberg jt 2004: 8 järgi). 1972. aastal võttis Dell Hymes kasutusele mõiste suhtluspädevus (ingl communicative competence), milles ta eristas keelepädevust ja sotsiolingvistilist pädevust, ning rõhutas konteksti tähtsust keeleoskuses. D. Hymes’i järgi sisaldub suhtluspädevuses see, mida grammatika võimaldab (ehk mis on süsteemi poolest võimalik), mida meie mõistmine võimaldab (psühholingvistiline aspekt) ja mis on ühiskonnas lubatud (ehk mis on sotsiokultuuriliselt kohane). Teisisõnu tähendab suhtluspädevus keeleteadmisi ja võimet neid kasutada (Douglas 2000: 25). 
Erinevad autorid on keeleoskuses näinud küll samu komponente, kuid kirjeldanud neid erinevate aspektide kaudu (Canale, Swain 1980, Canale 1983, Bachman 1990, Douglas 2000). Euroopa keeleõppe raamdokumendis (CEF 2001: 101-129) toodud mudelis on osa teadmisi ja oskusi liigitatud üldpädevusse, osa aga suhtluspädevusse kuuluvaks. A.-R. Hausenberg jt (2004) on esitanud need ülevaatlike joonistena (vt joonis 1 ja 2 ).

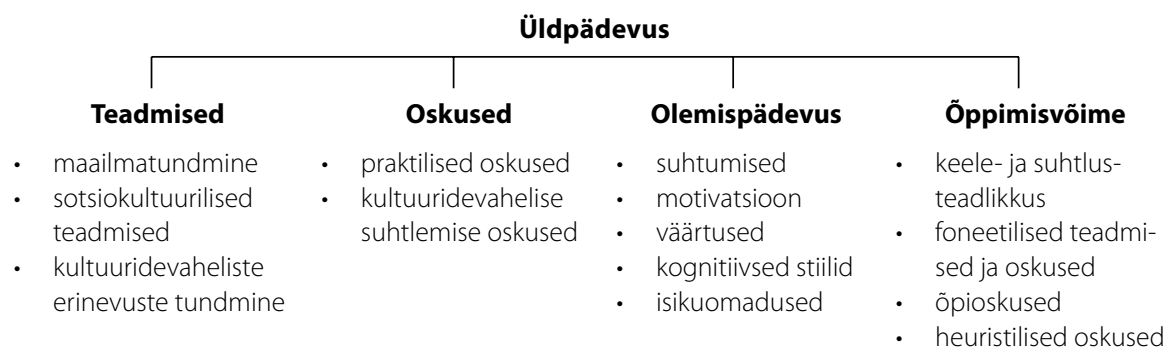

Joonis 1. Üldpädevuse komponendid keeleõppe raamdokumendi järgi (Hausenberg jt 2004: 11)

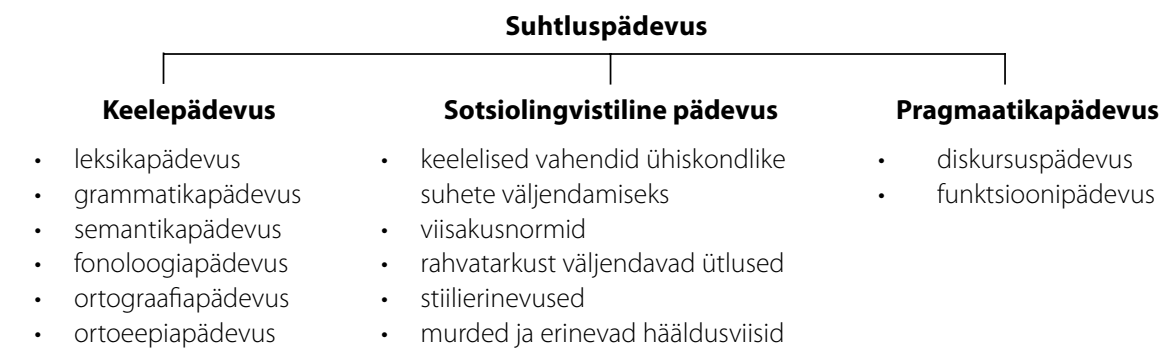

Joonis 2. Suhtluspädevuse komponendid keeleõppe raamdokumendi järgi (Hausenberg jt 2004: 11)

Ehkki üldpädevus ei ole suhtluspädevuse osa, on keelelisse suhtlemisse alati haaratud ka üldpädevuse komponendid. Eriti märgatav on see eriotstarbelises keelekasutuses, kus erialaspetsiifilised teadmised ja oskused mängivad olulist rolli.

Eriotstarbelise keeleoskuse mõõtmisel arutletakse tihti selle üle, mis on testi edukaks sooritamiseks olulisem, kas üldkeeleoskus või erialaspetsiifilised taustteadmised. Dan Douglas (2000: 29-40) väidab eri autoritele tuginedes, et kui keeletest ei ole kitsalt erialaspetsiifiline, on olulisem hea üldkeeleoskus, mis võimaldab taustteadmiste puudumist kompenseerida, samal ajal kui nõrka üldkeeleoskust taustteadmistega kompenseerida ei ole võimalik. Kui keeletest on aga väga erialaspetsiifiline ja mõistetav vaid selle valdkonna inimestele, muutuvad erialateadmised määravaks.

Samuti on leitud (Douglas 2000: 31-32), et teksti spetsiifilisust (erialasuse astet) ei mõjuta mitte niivõrd spetsiifilise sõnavara maht, kuivõrd see, kas nende sõnade tähendust tekstis selgitatakse või mitte. Mida erialaspetsiifilisem on tekst, seda rohkem eeldatakse, et lugeja või kuulaja on erialaga kursis ja seda vähem selgitatakse mõistete tähendust, mis teeb erialakaugele inimesele niisuguse teksti mõistmise väga raskeks. Seega näib teksti spetsiifilisus olevat sõltuvuses sellest, mil määral selle mõistmine nõuab erialaseid teadmisi, mida tekst ei sisalda. 
Et meie koostatud kuulamistestide sihtrühmaks olid kutsekoolide õpilased, mitte vastava eriala spetsialistid, lähtusime tekstide valikul ja kohandamisel sellest, et teema oleks õpilastele tuttav (olid seda eelmisel aastal õppinud) ja selle käsitlus tavainimesele mõistetav. Hoolimata sellest, et käsitleti erialaspetsiifilisi teemasid, olid tekstid valdavalt üldkeelsed.

\section{Tekstid}

Kuulamisoskuse õpetamise ja mõõtmise üheks suuremaks takistuseks on sobivate tekstide leidmine. Kui kirjalikke tekste on Interneti-ajastul suhteliselt lihtne leida ja kasutamiseks kohandada, siis suuliste tekstide töötlemine on raskendatud. Seetõttu kasutatakse tihti kuulamisoskuse arendamiseks kirjalikke tekste, mis kantakse suuliselt ette. Ometi on kirjalikud ja suulised tekstid oma olemuselt vägagi erinevad. Tiit Hennoste (2000: 1139-1141) toob välja viis kõne ja kirja erinevust:

1) kõne on tagasikerimatu, s.t kuulajal ei ole võimalik teksti mitu korda kuulata;

2) kõne on kustutamatu, s.t öeldut ei saa tagasi võtta;

3) kõne on lineaarne, s.t kuulaja kuuleb teksti sõnahaaval ja ei saa tekstis tagasi- ega edasivaateid teha;

4) kõne on seotud nii kõneleja kui ka kuulaja lühimälu mahuga, mistõttu korraga suudetakse töödelda $7 \pm 2$ ühikust koosnevat üksust;

5) kõne on visuaalne-auditiivne, s.t erinevalt kirjast saab kuulaja teavet ka vokaalsete vahendite (intonatsioon, rõhud, tämber, tempo, pausid) kaudu.

Samas erinevad suulised tekstid nii suhtlusviisi omaduste kui ka suhtlusolukorra poolest (Hennoste 2000: 1147). Suhtlusviisi omaduste poolest on suulised tekstid rohkem või vähem dialoogilised või monoloogilised ning rohkem või vähem spontaansed või redigeeritud. Näiteks peetakse loengut klassikaliseks monoloogiks, kuid ometi saab lektor kuulajate reaktsiooni jälgides tagasisidet, mis muudab loengugi mingil määral dialoogiks. Redigeerituse all peetakse silmas teksti eelnevat ettevalmistamist ja selles mõttes on enamik suulisi tekste mingil määral redigeeritud, kasvõi põhipunktide läbimõtlemise näol.

Suhtlusolukord võib olla vahetu või vahendatud ning argine või avalik (Hennoste 2000: 1148). Vahetu suhtlus võimaldab kuulajal anda kõnelejale kohest tagasisidet, mistõttu dialoog kujutab endast vestluspartnerite ühisloomingut. Salvestatud tekstid, nagu raadio- ja telesaated, aga ka keeleõppes kasutatavad kuulamismaterjalid, on vahendatud tekstid, mille puhul tagasiside andmine pole võimalik. Helisalvestiste puhul kaob kuulaja jaoks ka kõne visuaalne pool, sest pole näha kõnelejate kehakeelt, miimikat, žeste jne. Argises suhtlusolukorras on vooruvahetus tavaliselt vaba ja osalejate rollid võivad muutuda (näiteks võib küsijast saada vastaja ja vastupidi), avalikus suhtlusolukorras on aga rollid rangemalt määratud (on selge, kes küsib ja kes vastab, mis järjekorras kõneldakse jne).

Nii suhtlusviis kui ka suhtlusolukord mõjutavad seda, kui kerge on kuulajal teksti jälgida ja mõista. Võib oletada, et vahetust argisest dialoogist arusaamine on lihtsam, sest kuulajal on võimalik rääkijat katkestada ja selgitusi paluda. Samas kulgeb argivestlus ettearvamatult, mis võib selle jälgimise teiskeelsele kõnelejale 
hoopis raskemaks muuta. Avaliku vestluse määratletus võib aga teksti jälgimist hõlbustada. Igal juhul on dialoogi jälgimine kergem kui monoloogi jälgimine, sest monoloogi puhul dikteerib teksti töötlemise kiiruse rääkija kõnetempo. Eriti raske on jälgida redigeerimata monoloogi, millel puudub selge ülesehitus ja mis esitatakse kiire tempoga.

Loomulikult ei ole suhtlusviis ja suhtlusolukord ainsad kuulamisteksti mõistmist mõjutavad tegurid. Nii teksti teema tuntus, abstraktsuse aste, keeleline lihtsus kui ka esituse selgus mängivad oma osa selles, kui kerge või raske on kuulajal tekstist aru saada. Eksamiolukorras aga ei piisa pelgalt kuulamisteksti üldisest mõistmisest, vaid tuleb aru saada just sellest, millele keskendub ülesanne ning arusaamist ka nõutaval moel näidata. Seega kujuneb kuulamisülesande raskus teksti ja ülesande omaduste koosmõjus, millest olulisemad kajastuvad tabelis 1 (vt ka Buck 2001: 149-153, Alderson 2000: 282-285, Hausenberg jt 2004: 36-40, 57-61).

Tabel 1. Kuulamisülesande raskust mõjutavad aspektid

\begin{tabular}{|c|c|c|c|}
\hline & Lihtne & $\begin{array}{l}\text { Kuulamisülesande } \\
\text { täitmist mõjutav aspekt }\end{array}$ & Raske \\
\hline \multirow{5}{*}{$\begin{array}{l}\frac{5}{n} \\
\text { 岾 }\end{array}$} & Jutustav ja kirjeldav & Tekstitüüp & Arutlev ja analüüsiv \\
\hline & $\begin{array}{l}\text { Loogiline, hästi liigendatud, } \\
\text { selgete üleminekutega }\end{array}$ & Ülesehitus & $\begin{array}{l}\text { Kõrvalepõigetega, selge struk- } \\
\text { tuurita, ebaloogiline }\end{array}$ \\
\hline & $\begin{array}{l}\text { Igapäevane üldkeele sõna- } \\
\text { vara, lihtne lauseehitus }\end{array}$ & Keel & $\begin{array}{l}\text { Kõnekeelsed ja idiomaatilised } \\
\text { väljendid; keerulised lause- } \\
\text { konstruktsioonid }\end{array}$ \\
\hline & $\begin{array}{l}\text { Konkreetne, hästi tuttav, } \\
\text { igapäevane }\end{array}$ & Teema & $\begin{array}{l}\text { Abstraktne, vähetuttav, spet- } \\
\text { siifiline }\end{array}$ \\
\hline & $\begin{array}{l}\text { Aeglane, selge, madal } \\
\text { tämber, selgesti eristuvad } \\
\text { hääled }\end{array}$ & Esitus & $\begin{array}{l}\text { Kiire, segane, taustamüra, kõrge } \\
\text { tämber, monoloog või raskesti } \\
\text { eristatavad hääled }\end{array}$ \\
\hline \multirow{3}{*}{ 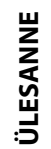 } & Valikulise teabe leidmine & Kuulamise eesmärk & Üksikasjade mõistmine \\
\hline & Tekstis otseselt antud & Vastus & Teksti põhjal järeldatav \\
\hline & Mittekeelelised valikud & Vastamise viis & Sõnaline vastus \\
\hline
\end{tabular}

Meie poolt kasutatud tekstid - intervjuu ja loeng - on T. Hennoste määratluse järgi mõlemad redigeeritud ja avalikud suulised tekstid, mis erinevad oma redigeerituse astmelt. Intervjuuks olid küsimused eelnevalt ette valmistatud, kuid intervjueeritav ei teadnud neid. Loengutekstid olid aga valmis kirjutatud ja salvestamisel need loeti maha. Mõlemad tekstid olid kuulajatele vahendatud tekstid, sest neid kuulati helilindilt. Ometigi on ka vahendatud dialoogi jälgimine lihtsam kui monoloogi jälgimine, sest intervjuu on kindla struktuuriga ja intervjueerija küsimused valmistavad kuulajat vastuste kuulamiseks ette. Samuti muudab dialoogi kuulamise lihtsamaks erinevate tämbrite esinemine.

Monoloogi - kas vahetu või vahendatud - kuulamine nõuab pikemaajalist keskendumist ja ei ole seetõttu madala keeleoskusega inimesele jõukohane. Loengu kuulamine on eriti raske, sest tavaliselt on sel juhul tegemist arutleva ja analüüsiva tekstiga abstraktsel, vähetuttaval ja spetsiifilisel teemal (vt tabel 1). Loengut saab kuulajale kergemaks muuta teksti aeglasema esituse, loogilise ülesehituse, lause- 
ehituse lihtsustamise ning sõnavara teadliku valiku ja vajalike selgitustega (vt Rost 2002: 162-164, 233-235). Võrreldes õppe-eesmärgilise lugemisega on loengu kuulamise puuduseks see, et on vaja palju meelde jätta, mistõttu tuleb märkmeid teha (Rost 2002: 162). Keeleõppija jaoks on aga kuulamise ajal märkmete tegemine ülesande täitmist raskendav asjaolu (vt tabel 1).

Suuliste ja kirjalike tekstide erinevuste mõistmine on oluline siis, kui (nagu see tihti juhtub) soovitakse keeleõppes kuulamisoskuse arendamiseks ja mõõtmiseks kasutada suuliselt esitatud kirjalikke tekste. Sel juhul tuleb kirjalik tekst suulise teksti eripära arvestades ümber töötada.

\section{Kuulamisoskuse aspektid}

Tavaelus sõltub see, kuidas me midagi kuulame nii tekstist kui kuulamise eesmärgist. Näiteks hommikul raadiot kuulates võib valikuliselt keskenduda vaid huvipakkuvale, näiteks ilmateatele või uudistele, aga võib ka kõike ühtviisi süvenenult kuulata, eriti siis, kui eesmärgiks on programmis kaasa rääkida. Kommunikatiivne keeleõpe lähtub eelkõige sellest, kuidas inimesed tavaelus keelt kasutavad. Kuulamisoskuse arendamisel ja mõõtmisel keskendutakse üldiselt neljale aspektile: teksti üldisele mõistmisele (üldkuulamine), mingi konkreetse teabe leidmisele tekstist (valikkuulamine), teksti üksikasjalikule mõistmisele (detailne kuulamine) ja kuuldu põhjal järelduste tegemisele (kuuldu tõlgendamine) (vt nt Harmer 2001: 201-202).

Uurimused (Shohamy, Inbar 1991, Buck 2001: 134 järgi) on näidanud, et kuuldu tõlgendamist nõudvad küsimused on testitavatele kõige raskemad, samas kui valikkuulamist ja detailset kuulamist nõudvate küsimuste raskus sõltub suuresti sellest, mis laadi teabele küsimus keskendub. Teksti põhiteema seisukohalt olulise teabe kohta koostatud küsimused on lihtsamad kui tõlgendamisküsimused, kuid nn triviaalküsimused, mis nõuavad täpsete, kuid teksti põhiteema seisukohalt ebaoluliste üksikasjade mõistmist, "käituvad" ettearvamatult: võib juhtuda, et nõrgad õpilased vastavad neile paremini kui tugevad õpilased. See tähendab, et triviaalküsimused muudavad testi tulemused ebausaldusväärseks, mistõttu tuleks neid kuulamistestides vältida (Buck 2001: 137).

Ka meie poolt kasutatud tekste - vestlust ja loengut - võib kuulata erinevatel eesmärkidel ja seega erinevalt. Tavaliselt on aga vestluse pealtkuulamisel tegemist mingi konkreetse teabe otsimisega ja kuuldust järelduste tegemisega; loengu puhul on lisaks konkreetse teabe leidmisele oluline üksikasjade märkamine ja üleskirjutamine. Loetletud kuulamisoskuse aspekte soovisimegi testidega mõõta.

\section{Ülesandetüübid}

Kui tavaelus määrab kuulamise eesmärgi inimese huvi või vajadus, siis keeleõppes ja keeleoskuse mõõtmisel antakse kuulamise eesmärk ülesandega. Seega on kuulamisoskuse mõõtmine alati vahendatud, kusjuures vahendajaks on ülesanne, mis võib ise testitulemusi mõjutada. Näiteks kui küsimus on mitmeti mõistetav, võib kuulaja sellele valesti vastata mitte seetõttu, et ta kuulamisteksti ei mõistnud, vaid seetõttu, et ta mõistis küsimust teisiti, kui selle koostaja oli planeerinud. 
Üheks põhimõtteks keeleoskuse mõõtmisel on võimalikult erinevate ülesandetüüpide kasutamine (vt nt Alderson jt 1995: 44-46). Põhjuseks on see, et igal ülesandetüübil on oma eelised ja puudused ning mõned tüübid sobivad teatud oskuste mõõtmiseks paremini kui teised. Mida rohkem eri ülesandetüüpe kasutada, seda kindlam võib olla, et mõõtmistulemused on usaldusväärsed.

Ülesandetüübist oleneb ka kuulamistesti raskus. Kõige parem oleks kuulamisoskust mõõta n-ö puhtalt, s.t teisi osaoskusi kasutamata. See on paraku enamalt jaolt võimatu, sest testitavad peavad tavaliselt lisaks teksti kuulamisele küsimusi lugema. Kui aga ülesanne nõuab veel sõnalise vastuse kirjutamist, on see eriti raske ja selliseid ülesandeid peetakse jõukohaseks vaid kõrgematel keeleoskustasemetel. Samuti tuleb seda tüüpi ülesande koostamisel arvestada, et testi sooritajal oleks piisavalt aega eeldatavad vastused kuulamise käigus kirja panna. Üldiselt eelistatakse siiski valikvastustega ja järjestamisülesandeid, kus testitavad kirjutavad vaid numbreid/tähti või teevad ristikesi/linnukesi. Kuulamisoskuse mõõtmiseks sobib eriti hästi piltide valimine või järjestamine, sest sellisel juhul ei ole testitavatel vaja kasutada ka lugemisoskust.

Valikvastustega ülesandel on mitmeid alltüüpe sõltuvalt valikute arvust ja liigist. Valikuid võib olla 2-4, mõnikord rohkemgi. Kahe valikuga ülesandeks on näiteks öige-vale vastusega küsimus, mille suureks puuduseks on see, et eksaminandidel on vastuseid huupi märkides 50-protsendiline võimalus tabada õige vastus. Seetõttu peaks sedalaadi küsimusi olema palju, et oletamise mõju vähendada (Alderson jt 1995: 51). Valikvastustega küsimusi on lihtsam koostada valikulise info mõistmise ja teksti peamõttest arusaamise kontrollimiseks, kuid seda tüüpi ülesannet saab kasutada teistegi kuulamisoskuse aspektide mõõtmiseks.

Kuulamistesti järjestamisülesanne nõuab testi sooritajalt piltide või tekstide järjestamist vastavalt kuulatavale tekstile. Ülesanne on raskem, kui vastusevariante on rohkem kui tulemus seda nõuab, kuna sel juhul peab õppija lisaks järjestamisele ka otsustama, kas mingi variant üldse vastusesse kuulub. Järjestamisülesanne võib olla problemaatiline nii koostamise kui hindamise seisukohast. Koostamisel tuleb silmas pidada, et tekstis sisalduksid selged vihjed, mis aitavad vastuseid järjestada, nii et vaid üks tulemus oleks võimalik ja õige. Tavaliselt tuleb teksti koostajal nimetatud vihjeid lisada. Kuna testisooritaja võib ülesande täitmise käigus eksida, seisneb probleem selles, kuidas osaliselt õiget vastust hinnata. Harilikult loetakse osaliselt õige vastus valeks ning arvesse läheb vaid täiesti õige järjestus (Alderson 2000: 221).

Ülesandetüüpide valikul lähtusime põhimõttest kasutada tuntud ülesandetüüpide kõrval ka neid, mida eesti keele tasemeeksamitel ei kasutata ja mis suure tõenäosusega on õppijatele võõrad (vt tabel 2). Samas sõltus ühe või teise tüübi kasutamine ka võimalustest, mida tekst pakkus. Õppijatele eeldatavasti vähem tuttavateks kuulamisülesanneteks võib pidada

1) järjestamisülesandeid,

2) valikvastustega küsimusi, milles valikud on antud tabelis,

3) mitut õiget vastust eeldavaid valikvastustega küsimusi,

4) lühivastuste märkimist nõudvat tabeli täitmist.

Nagu tabelist 2 ilmneb, sisaldasid kõige rohkem eri ülesandetüüpe ehituse ja koka erialale mõeldud testid. 
Tabel 2. Testides kasutatud ülesandetüübid erialati

\begin{tabular}{|c|c|c|c|c|c|c|c|c|}
\hline \multirow{2}{*}{ Eriala } & \multirow{2}{*}{ 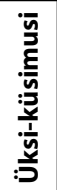 } & \multicolumn{4}{|c|}{ Valikvastused } & \multicolumn{2}{|c|}{ Järjestamine } & \multirow{2}{*}{$\begin{array}{c}\text { Lühivastus } \\
\text { Tabel }\end{array}$} \\
\hline & & $3-4$ & Tabel & $\begin{array}{c}\text { Õige- } \\
\text { vale }\end{array}$ & $\begin{array}{l}\text { Mitu } \\
\text { oiget }\end{array}$ & Tekst & Pildid & \\
\hline Arvutiteenindus & 12 & & & $x$ & & & & \\
\hline Autolukksepp-maaler & 6 & $x$ & & & $x$ & $x$ & & \\
\hline Ehitus & 14 & $x$ & $x$ & $x$ & $x$ & $x$ & $x$ & \\
\hline Hotelliteenindus & 11 & & & $x$ & & & & \\
\hline Keskkonnakaitse & 11 & & & $x$ & & & & \\
\hline Kokk & 18 & $x$ & & $x$ & $x$ & & & $x$ \\
\hline Laomajandus & 11 & & & $x$ & & & & \\
\hline Sotsiaalhooldus & 8 & $x$ & & $x$ & $x$ & & & \\
\hline Turismikorraldus & 7 & $x$ & & & $x$ & & & \\
\hline Ärikorraldus & 7 & $x$ & & & & & & \\
\hline
\end{tabular}

\section{Kuulamistestide koostamine}

Kuulamistestide koostamist alustasime sobivate tekstide leidmisest. Kuna esimene tekst oli üldkeelne intervjuu, otsustasime selle salvestada võimalikult loomulikuna. Seetõttu mõtlesime küll valmis küsimused, kuid intervjueeritavale ütlesime vaid teema. Intervjueeritav oli eesti keelt teise keelena valdav inimene, mistõttu tema keelekasutus isegi tööst rääkides on eesti keele õppijatele mõistetavam, sest on kirjakeelsem kui eesti keelt emakeelena kõnelejatel spontaanses vestluses.

Teiseks tekstiks valisime erialaloengu ning seetõttu tutvusime õppekavadega, et välja selgitada esimesel aastal läbitud ainekursused. Sellega soovisime tagada teema tuntuse, mis on B1/B1+ tasemel kuulamisel veel oluline. Valisime eriala seisukohalt oluliste ainete hulgast teemad, mille kohta otsisime sobivaid populaarteaduslikke tekste. Valitud tekstid töötasime ümber loenguteks. Kohandamisel võtsime arvesse suuliste tekstide eripära. Kuna kõne on seotud nii kõneleja kui kuulaja lühimälu mahuga, vähendasime tunduvalt tekstis sisalduvat infot, eemaldades ülearused detailid. Samuti lühendasime segmentide pikkust nii, et need jääksid enamikus $7 \pm 2$ ühiku raamesse. Kõne lineaarsus tingib selle, et kõneleja peaks ise lisama teksti edasivaateid, mida kuulaja teha ei saa. Seetõttu muutsime tekstide ülesehitust. Et kuulajad olid eesti keelt teise keelena õppijad, lihtsustasime tekstide sõnavara ja lauseehitust. Lisas 2 on näiteks toodud katkend ehituseriala õpilastele koostatud testi lähtetekstist ja selle ümbertöötatud variandist, millest on näha tehtud muudatuste ulatus.

Tekstide kohandamisele järgnes nende lindistamine, sest oluline on kuulamistesti ülesanded kirjutada kuulatud, mitte loetud tekstile. Teksti üleskirjutuselt ei selgu esitamise tempo ja see, kuidas rääkija midagi rõhutab, mistõttu võib olla võimatu sellele kirjutatud ülesannet kuulamisel täita. Samas aga tekitab teksti eelnev lindistamine teatud probleeme. Nimelt võib selguda, et teksti põhjal on raske ülesannet koostada, kuid kuna tekst on juba lindistatud, ei saa seda ka enam muuta. 
Ülesannete koostamisel lähtusime eelkõige sellest, kuidas antud teksti tavaelus kuulatakse. Seetõttu oli põhirõhk valik-ja detailsel kuulamisel, ehkki intervjuu kohta koostatud küsimuste hulgas esines ka tõlgendamisküsimusi. Nagu tabelist 2 ilmneb, kujunes kõige enam kasutatud ülesandetüübiks õige-vale vastusega küsimus, mida kasutasime seitsmes testis kümnest, kusjuures kolme testi puhul oli see ainuke kasutatud ülesandetüüp. Pooled testid sisaldasid rohkem kui ühte ülesandetüüpi. Kõige rohkem eri ülesandetüüpe (kuut) sisaldas ehituserialale koostatud test, mis on toodud lisas 2.

\section{Testide läbiviimine ja tulemused}

Kuna erialati oli lähetatuid vaid 4-20 õppijat, siis ei saanud testide sooritamist statistiliselt analüüsida. Samuti esines probleeme testide usaldusväärse läbiviimisega. Näiteks otsustati kohapeal ühe testi läbiviimisel mitte kasutada meie koostatud testi, vaid testiti oppijaid enda meelest sobivate materjalidega. See seab kahtluse alla teistegi testide tulemused ning muudab statistilise analüüsi mõttetuks. Seega põhinevad järgnevad üldistused tähelepanekutel, mida me tegime testide hindamise käigus.

Ülesandetüübid, mida tasemeeksamitel ja seega ilmselt ka õpetuses ei kasutata, on õppijatele võõrad ja selliste ülesannete lahendamine valmistas raskusi. Et raskuse põhjus peitus just ülesandetüübis, näitab asjaolu, et paljudel juhtudel polnud esimesel testimisel ülesannet täidetud või täideti vaid osaliselt. Teisel testimisel aga olid samad õppijad ülesannet vähemalt täita üritanud. Üheks niisuguse ülesande näiteks on koka erialale koostatud lühivastuste märkimist nõudev tabeli täitmine.

Teiseks näiteks võib tuua ehituse erialale koostatud järjestusülesande, milles kuulamise käigus tuleb ette antud plaatimistoimingud järjestada õigesti (vt lisa 2). Õppijad, kes esimese soorituse käigus polnud ülesannet üldse teinud, olid teisel testimisel tabelit vähemalt üritanud täita, mõnel juhul isegi osaliselt õigesti. Õppijad, kes aga olid esimesel testimisel toimingud järjestanud valesti, täitsid teise sooritusega ülesande enamasti õigesti.

Hästi vastati küsimustele, mis eeldasid konkreetse teabe leidmist tekstist. Sellest võib järeldada, et õpilased on omandanud selektiivse kuulamise võtted.

Raskusi valmistasid küsimused, millele vastamiseks oli vaja kuuldu põhjal järeldusi teha või tekstis sisalduvat teavet kombineerida. See võib tähendada, et õpilaste kuulamisoskus ei olnud piisav, et kogu teksti mõttega jälgida, saadud teavet varasemaga võrrelda ja järeldusi teha. Samas võib see aga märku anda sellest, et õpilased pole harjunud sedalaadi kuulamisülesannetega ega oska nendele seetõttu õigesti läheneda.

Testitavate soorituse hindamisel tehtud tähelepanekud kinnitavad taas, et kolme nädala jooksul, nagu ette arvatud, õppijate kuulamisoskus märgatavalt ei paranenud. Tõsiasi, et paljud õppijad hindasid lähetuse järel oma keeleoskust paremaks (Vaagen 2005), võib tuleneda sellest, et õppijad said positiivse kogemuse eesti keele eesmärgipärasest kasutamisest keelekeskkonnas, mis eelkõige parandas nende enesekindlust ja usku võimesse eesti keeles toime tulla. Seetõttu on sellised lähetused õpilastele äärmiselt vajalikud, kuid nende eesmärgid peavad olema realistlikud. 


\section{Kokkuvõte}

Kutsekooliõpilastele mõeldud kuulamistestide koostamise protsess kinnitas taas, et hea testi eeltingimuseks on sobiv tekst. Suuliste tekstide leidmine ei ole paraku lihtne, mistõttu tuleb tihti kohandada kirjalikke tekste. Seejuures tuleb kindlasti arvestada suuliste tekstide eripära.

Ülesandetüüpide valikul tuleb lähtuda põhimõttest, et igas testis tuleks kasutada vähemalt kahte tüüpi, et vähendada ülesandetüübi mõju testi tulemustele. Samade ülesandetüüpide kasutamine eksamil võib viia selleni, et õppetöös harjutakse ühtede ülesannetega ja omandatakse teatud strateegilised oskused nende ülesandetüüpide lahendamiseks, kuid harjutamise käigus kuulamisoskus tegelikult ei parane ja tundmatu ülesandetüübi kasutamine võib kaasa tuua ülesande ebaõnnestunud sooritamise. Eri ülesandetüüpide kasutamine õpetuses arendab kuulamisoskust laiemalt ja on eelduseks keeletestide edukale sooritamisele.

Kuulamistekstide kohta küsimusi koostades tuleb lähtuda tekstitüübist ja sellest, kuidas me analoogseid tekste tegelikult elus kuulame. Küsimusi tuleks esitada eelkõige olulise teabe kohta tekstis, mitte ebaoluliste detailide kohta. Samuti tuleks silmas pidada, et küsimusi ei esitataks mitte ainult tekstis otseselt sisalduva info kohta, vaid kontrollitaks ka kuuldu põhjal järelduste tegemise oskust.

\section{Kirjandus}

Alderson, Charles J. 2000. Assessing Reading. Cambridge: Cambridge University Press.

Alderson, Charles J.; Clapham, Caroline; Wall, Dianne 1995. Language Testing Construction and Evaluation. Cambridge: Cambridge University Press.

Bachman, Lyle F. 1990. Fundamental Considerations in Language Testing. Oxford: Oxford University Press.

Buck, Gary 2001. Assessing Listening. Cambridge: Cambridge University Press.

Canale, Michael 1983. On some dimensions of language proficiency. - J. W. Oller (Ed.). Issues in Language Testing Research. Rowley, Mass.: Newbury House, 333-342.

Canale, Michael; Swain, Merrill 1980. Theoretical bases of communicative approaches to second language teaching and testing. - Applied Linguistics 1 (1), 1-47.

$\mathrm{CEF}=$ Council of Europe. 2001. Common European Framework of Reference for Languages: Learning, Teaching, Assessment. Cambridge: Cambridge University Press.

Douglas, Dan 2000. Assessing Languages for Specific Purposes. Cambridge: Cambridge University Press.

Harmer, Jeremy 2001. The Practice of English Language Teaching. Harlow: Pearson Education Ltd.

Hausenberg, Anu-Reet; Kikerpill, Tïna; Rõigas, Maia; Türk, Ülle 2003, 2004. Keeleoskuse mõõtmine. Käsiraamat. Tallinn: TEA Kirjastus.

Hennoste, Tiit 2000. Sissejuhatus suulisesse eesti keelde I. Taust ja uurimisobjekt. - Akadeemia 5, 1118-1150.

Hymes, Dell H. 1972. On communicative competence. - J. B. Pride, J. Holmes (Eds.). Sociolinguistics. Harmondsworth: Penguin, 269-293.

Rost, Michael 2002. Teaching and Researching Listening. Harlow: Pearson Education Limited.

Vaagen, Anu 2005. Eesti keele kui teise keele oskuse arendamisest EL Phare keeleõppe- ja lähetusprojekti näitel. - Ettekanne konverentsil "Emakeel ja teised keeled V”, Tartu Ülikool, 17.-18.11. 


\section{Kaudviited}

Carroll, John B. 1961. Fundamental considerations in testing for English proficiency of foreign students. - Testing the English Proficiency of Foreign Students. Washington, D.C.: Center for Applied Linguistics, 31-40.

Lado, Robert 1961. Language Testing. London: Longman.

Shohamy, Elana; Inbar, Ofra 1991. Validation of listening comprehension tests: The effect of text and question types. - Language Testing 8 (1), 23-20.

\section{LISA 1. Lähteteksti kohandamise näide}

\section{Katkend lähtetekstist (260 sõna):}

.. Vuukide täitmine võib alata, kui plaatimissegu on kivinenud pakendil nõutud aja. Vuugitäite värv valitakse esteetilisest seisukohast lähtudes. Vuugitäiteid on saadaval erinevate laiusega vuukidele, ning erineva kasutusalaga ruumidele. On saadaval ka vuugitäite omadusi täiendavad lisaained. Vuugitäide segada vastavalt juhistele pakendil ning kanda plaatide pinnale vuukide suhtes diagonaalselt. Selleks kasutatakse kummist vuugilabidat.

Kui vuugitäide on pindmiselt kuiv kuid veel elastne, pestakse plaatide niiske käsnaga puhtaks. Poorsed plaadid on soovitatav katta enne vuukimist pinnakaitseõliga. Vuugitäitesegu ei tohi lasta plaatide pinnale kivistuda. Juhul kui siiski vuugitäide on jäänud õigeaegselt eemaldamata ning plaatide külge kivistunud, on abiks spetsiaalsed kemikaalid. Kui vuugid on tahenenud kuid mitte lõplikult kivistunud, puhastage plaatkatte pinda pehmepõhjalise hõõruti või jämedakoelise kangaga.

Järelhoolduseks on hea vuuke veel paari ööpäeva jooksul mõned korrad niisutada. Plaatkatte nurgavuugid, põranda-seina ühenduskohad ning kokkupuutekohad teiste tarindite, näiteks lengide ja sisustusega täidetakse elastse sanitaarsilikooniga. Elastne täide on vajalik, kuna erinevast materjalist tarindid elavad ning liiguvad pisut erinevalt. Et on saadaval vuugitäitega sobivates toonides silikoone ei mõju need vuugid häirivalt.

Vuugiservadele paigaldatakse teip, et silikoon ei satuks ülemäära plaatide peale. Silikoon kantakse vuukidesse spetsiaalse püstoliga, silutakse märja sõrme või niisutatud puupulgaga. Teip eemaldatakse peale silikooni paigaldamist ning silutakse märja sõrmega veelkord üle, et tasandada teibi eemaldamisest tekkinud randid. Looduskividest plaatkatte puhul on oluline valida neutraalne sanitaarsilikoon, et vältida plaadiservade värvumist silikoonmassis leiduvate kemikaalide mõjul. Lisaks silikooniga täitmisele võib plaatkatte sise- ja välisnurkades ning vabaserva lõppedes kasutada ka dekoratiivseid plastikliiste. Plastliist aga ei asenda vuukide tihendamist.

Põrandakütte sisselülitamisega tuleb oodata vähemalt nädal peale tööde lõpetamist. Ruumi kasutamisega, näiteks vannitoa puhul oodata kuni materjalid on kuivanud pakendil toodud aja. .. (Veiko Ikkonen, Mira Ehitusmaterjalid OÜ tegevjuht)

\section{Katkend kohandatud tekstist (125 sõna):}

.. Vuukide täitmine võib alata, kui plaatimissegu on kivinenud pakendil nõutud aja, mis võib olla üks kuni kolm ööpäeva. Vuugitäide segatakse vastavalt juhistele 
pakendil. Kõigepealt kantakse vuugitäide plaatide pinnale vuukide suhtes diagonaalselt. Selleks kasutatakse kummist vuugilabidat.

Seejärel, kui vuugitäide on pindmiselt kuiv, pestakse plaadid niiske käsnaga puhtaks. Kuivanud plaatide pind puhastatakse hoolikalt kuiva lapiga.

Lõpuks täidetakse plaatkatte nurgavuugid ning põranda ja seina ühenduskohad silikooniga. Elastne täide on vajalik, kuna erinevast materjalist tarindid elavad ning liiguvad pisut erinevalt.

Vuugiservadele paigaldatakse teip, et silikoon ei satuks plaatide peale. Silikoon kantakse vuukidesse spetsiaalse püstoliga, silutakse märja sõrme või niisutatud puupulgaga. Teip eemaldatakse kohe peale silikooni panemist.

Põrandakütte võib sisse lülitada mitte enne kui nädal peale tööde lõpetamist. Plaaditud ruumi võib hakata kasutama, kui materjalid on kuivanud pakendil ettenähtud aja...

\section{LISA 2. Ehituse erialale koostatud kuulamistest}

Tekst 2. Lugege küsimusi töölehel. Märkige vastused ristiga.

\section{NÄIDE. o. Eelmisel korral räägiti põhjalikult}

$\begin{array}{ll}\text { aluspinnast } & \square \\ \text { plaatimisest } & \square \\ \text { vuukimisest } & \square\end{array}$

1. Töövahendid, mida kasutatakse plaatimisel ja vuukimisel, on (NB! märkige KÕIK teksti järgi õiged vastused!)

$\begin{array}{ll}\text { segukamm } & \square \\ \text { vuugilabidas } & \square \\ \text { vuugisegu } & \square \\ \text { käsn } & \square \\ \text { silikoon } & \square\end{array}$

\section{Plaatimiseks on vaja}

Aluspinnad ette valmistada

Ruumi tuulutada

Põrandat kütta

3. Märgi tabelisse ristiga (X), kas aluspind on täiesti stabiilne, teatud määral stabiilne või ebastabiilne.

\begin{tabular}{|l|l|l|l|}
\hline & Täiesti stabiilne & Teatud määral stabiilne & Ebastabiilne \\
\hline vana betoon & & & \\
\hline hiljuti valatud betoon & & & \\
\hline puitalusel sein & & & \\
\hline köetav põrand & & & \\
\hline soemüür & & & \\
\hline
\end{tabular}


4. Järjesta plaatimistööd (1-5) lektori soovituste järgi. (NB! 1. töö on märgitud)

$\begin{array}{ll}\text { valmista plaatimissegu } & \square \\ \text { kammi segu läbi } & \square \\ \text { kanna segu aluspinnale } & \square \\ \text { koputa plaadid kinni } & \square \\ \text { suru plaadid segusse } & \square\end{array}$

\section{Kas väide on õige või vale?}

\begin{tabular}{|l|l|l|}
\hline Väide & Õige & Vale \\
\hline Esimesena plaaditakse seinad. & & \\
\hline Plaatimist alustatakse nurkadest. & & \\
\hline Töö kvaliteeti peab kontrollima mitu korda. & & \\
\hline
\end{tabular}

6. Järjesta vuukimistööd (1-3) lektori soovituste järgi. Märgi number pildi kõrvale kastikesse.
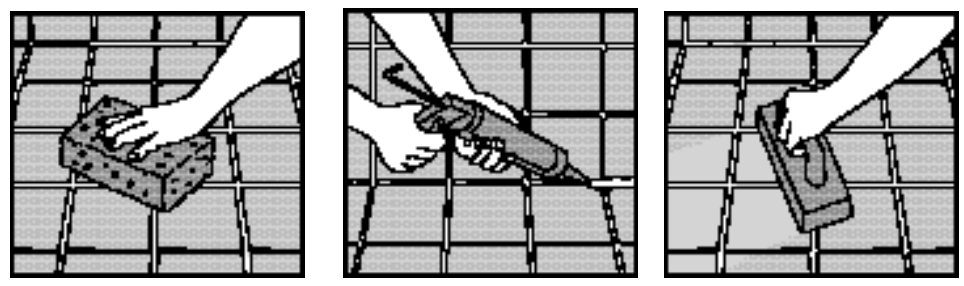

\section{Teipi kasutatakse}

plaatide kaitsmiseks

vuugiservade kaitsmiseks

vuukide kaitsmiseks

\section{Põrandat võib kütta}

2 päeva pärast plaatimist

5 päeva pärast plaatimist

8 päeva pärast plaatimist

Tiina Kikerpilli (Tartu Ülikool) uurimisvaldkondadeks on võõrkeelte õppimine ja õpetamine, keeleoskuse mõõtmine, arvutitugine keeleõpe.

tiina.kikerpill@ut.ee

Ülle Türk (Tartu Ülikool) teaduslikeks huvialadeks on keeleoskuse mõõtmine, võõrkeelte õppimine ja õpetamine, kirjaliku väljendusoskuse ja kriitilise lugemisoskuse õpetamine, kultuuridevaheline kommunikatsioon ning Suurbritannia kultuur.

ulle.turk@ut.ee 


\section{MEASURING SPECIFIC PURPOSE LANGUAGE ABILITY: TEXTS AND TASKS IN ESTONIAN AS A SECOND LANGUAGE LISTENING TESTS}

\section{Tiina Kikerpill, Ülle Türk}

University of Tartu

Although tests of Estonian as a second language (L2) have been developed for more than ten years, most of them have been designed to test learners' competence in general Estonian. Testing of Estonian for specific purposes has been neglected so far. The EU Phare Project of 2004-2005 "Developing the Estonian language competence in vocational schools with the language of tuition other than Estonian" offered a welcome opportunity to develop ten different listening tests for students of ten specialities.

The article discusses the process of test development focusing on different models of language competence and the characteristics of specific purpose language ability, various aspects of listening comprehension, features of spoken texts and the principles that need to be followed when transforming written texts into spoken ones, principles of choosing appropriate task types and the general procedure for developing listening tests.

The test development process highlighted a number of issues. One of the major obstacles to designing good listening tests turned out to be a lack of appropriate oral texts. Therefore, it was necessary to use some written texts and adapt them bearing in mind the differences between the spoken and written languages. In designing the tasks, the skills used in real-life listening to the same types of texts were taken into account and an attempt was made to tap similar skills. To minimize the test method effect, each test employed at least two different task types.

As the number of students who took each test was very small, it is not possible to analyse the results statistically and to draw any reliable generalizations from them. It was clear, however, that students found it easier to answer the questions asking for specific information than those obliging them to obtain information from various parts of the text and combine it in a new way. Similarly, familiar task types proved to be easier than those that had not been used in Estonian language examinations before.

Keywords: Estonian as a second language, language tests, development and assessment of listening comprehension 